Asian J. Med. Biol. Res. 2020, 6 (2), 130-137; doi: 10.3329/ajmbr.v6i2.48043

\author{
Asian Journal of \\ Medical and Biological Research \\ ISSN 2411-4472 (Print) 2412-5571 (Online) \\ www.ebupress.com/journal/ajmbr
}

Review

\title{
Impact of COVID-19 on food safety and security in low and middle income countries
}

Md. Nasir Uddin ${ }^{1}$, Badrul Alam ${ }^{1}$, SK Shaheenur Islam ${ }^{1,2}$, Mohammad Arif ${ }^{1}$, Md. Mahbubul Alam ${ }^{3}$ and S. M. Lutful Kabir ${ }^{*}$

\author{
${ }^{1}$ Department of Microbiology and Hygiene, Bangladesh Agricultural University, Mymensingh-2202, \\ Bangladesh \\ ${ }^{2}$ Department of Livestock Services, Krishi Khamar Sarak, Farmgate, Dhaka-1215, Bangladesh \\ ${ }^{3}$ Bangladesh Centre for Advanced Studies, Road-16/A, Gulshan-2, Dhaka-1212, Bangladesh
}

*Corresponding author: Professor Dr. S. M. Lutful Kabir, Department of Microbiology and Hygiene, Bangladesh Agricultural University, Mymensingh-2202, Bangladesh. Phone: +8801754987218; E-mail: lkabir79@bau.edu.bd

Received: 13 June 2020/Accepted: 29 June 2020/ Published: 30 June 2020

\begin{abstract}
The occurrence of COVID-19 which causes severe acute respiratory infection has produced a large global outbreak with major public health concern. Since Chinese wet market (LBM) has been blamed to be linked with this global pandemic of COVID-19 as the noble virus has supposed to be transmitted from a wild species, however, this is not yet established the association of SARS-Cov-2 transmission via animal to human or food chain. Moreover, it has been recognized to spread human-to-human transmission by inhalation of droplets or direct contact. Besides the devastating effects of SARS-Cov-2, world has been experiencing the impact of food safety and security as the effect due to global lockdown resulting a wide range of new challenges of economic growth and societal burden. In this review, we have focused on effect of corona virus on food system that included food safety, food security during lockdown, and prevention and control options have been emphasized to keep normalcy of livelihood of general people in low and middle income countries (LMICs). Since the global economy has been downed deeper into a financial crunch, the government efforts are underway to bolster up the priorities with the limited resources, and further funding allocation decision is obligatory for the targeted communities those are affected most due to the swath of pandemic threat of COVID-19.
\end{abstract}

Keywords: SARS-Cov-2; COVID-19; food safety and security; low and middle income countries (LMICs); pandemic

\section{Introduction}

The Coronavirus $(\mathrm{CoV})$ is considered as one of the most dangerous viruses that affects humans and causes devastating losses to mankind. Coronaviruses (CoVs) belong to the subfamily Orthocoronavirinae in the family Coronaviridae, Order: Nidovirales. There are four genera within the subfamily Orthocoronavirinae, namely Alpha-coronavirus $(\alpha-\mathrm{CoV})$, Betacoronavirus $(\beta-\mathrm{CoV})$, Gammacoronavirus $(\gamma-\mathrm{CoV})$, and Deltacoronavirus $(\delta$ $\mathrm{CoV}$ ) (Yang and Leibowitz, 2020). Coronaviruses are commonly found in animals but have the ability to infect human like MERS-CoV, SARS-CoV and most recently identified the novel corona virus (SARS-CoV-2) causing COVID-19 in humans. The CoV genome is an enveloped, positive-sense, single-stranded RNA with a size varying between $26 \mathrm{~kb}$ and $32 \mathrm{~kb}$, the largest genome of known RNA viruses. Both $\alpha-$ and $\beta-\mathrm{CoV}$ genera are known to cause infection in mammals; however, infection with $\delta$ - and $\gamma$-CoVs found in birds. The genome of the SARS-CoV-2 is similar to the SARS-CoV-1 and MERS-CoV viruses originated from bat (Li et al., 2005). It shows that, the SARS-CoV-2 whole-genome aligned with the genomes of the bat corona viruses (Bat-CoV and Bat-CoV RaTG13) in Rhinolophus affinis species of Yunnan province with $79.6 \%$ sequence identity to SARS-CoV, and that represents 96\% identical at the whole-genome level (Zhou et al., 2020).

The SARS-Cov-2 virus has been primarily captured in Wuhan city of China and now this infection has been spread though movement of people throughout the world ( $\mathrm{Lu}$ et al., 2020). Therefore, a formal declaration was 
made by the WHO as Public Health Emergency of International Concern (PHEIC). The WHO has mentioned that SARS-CoV-2 is considered to be a zoonotic virus derived from the bats; however, it is plausible to have passed in an intermediate host to cause infection in humans (Shahidi, 2020). This virus is also airborne which spreads through infected respiratory droplets of cough and sneeze. Infected person shows the flu-like symptoms of COVID-19 normally 2 to 14 days after exposure and include a series of ailments coughing, sore throat, fever, muscle and body aches (CDC, 2020), and even loss of taste or smell in few cases (Business Insider, 2020 ${ }^{\mathrm{a}}$ ). Transmission takes place by touching the objects (surface having viral particles) and then it can easily enter into human body via touching of natural orifices like mouth, nose, and eyes. Though these symptoms are mild, however, it may lead to fatal pneumonia or life threating complications like acute respiratory difficulty with the comorbidity of diabetes or heart diseases in older patients. The virus has challenged the global public health systems that initiated disruption in livelihood of mass people. Within a four months duration, the virus has spread throughout the world by travelling of infected people that indicates human to human transmission (Lu $e t$ al., 2020).

The WHO has declared the COVID-19 outbreak as the sixth public health emergency of international concern on 30 January 2020, followed by Ebola in the Democratic Republic of Congo in 2019, Zika in 2016, Ebola in West Africa in 2014, polio in 2014 and H1N1 in 2009. Therefore, there has been an urgent need among the health workers, governments and the public to work together globally on timely basis to prevent its spread (Yoo, 2020). The first COVID-19 positive case in Bangladesh was reported on 08 March, 2020, and as of June 29, 2020 a total number of 141,801 confirmed cases identified, of which 1,782 deaths recorded in Bangladesh $($ WHO, 2020 $)$. The number of COVID cases have been escalated exponentially after strengthening the sample testing facilities in all over the country (60 laboratories both government and private hospitals are functional on sample testing). The outbreak has taken at its highest peak in June, 2020 and is still ongoing. Available data allows us to understand how quickly the number of confirmed cases increased in Bangladesh compared with some other countries around the world (WHO, 2020 $)$.

The impacts of COVID-19 are not difficult to visualize. Interruption of livelihoods of marginalized communities, breaking the supply chains, less access to health and nutrition facilities, and affected social safety net will directly or indirectly influence the food security (IFPRI, 2020). The impact on food security will have long-lasting effects on the whole strata of food supply chains namely producers, suppliers/middleman, sellers, and finally consumers (Hobbs, 2020). At present, there is no instances of COVID-19 virus has been transmitted by livestock and poultry species or fish responsible for the current pandemic. The live animals may be a source of pathogens, so, all types of food can potentially be contaminated through direct or indirect contact with contaminated equipment, surfaces or even environments $\left(\mathrm{FAO}, 2020^{\mathrm{a}}\right)$.

\section{Food safety during pandemic situation}

Supplying safe food is an important factor for public health and nutrition. Consumption of safe and nutritious food induce our body immunity, and our body can combat against different diseases even COVID-19 as a food safety ground. This is a significant factor for maintaining good health. Although WHO, FAO and US-FDA suggest that consumption of contaminated food is not the way of transmission of COVID-19, but there have been a lot of chances of getting infection by other foodborne pathogens (The Financial Express, 2020 a) that may weaken our body immunity.

The COVID-19 has been considered as zoonotic disease like SARS and MERS, due to its transmission dynamics (Galanakis, 2020; Tiwari et al., 2020). Animals are well-thought to be the primary reservoir of coronavirus where some strain may cause infection in human (Mahmoud, 2020; Guo et al., 2020). According to the information of the WHO, coronavirus has originated from a wet market at Wuhan in Hubei province of China, where different types of seafood, live domestic and wild animals, and birds have been sold (Tiwari et al., 2020). The wild bats, marine snakes, pangolins etc. are considered to be the sources of this virus; however, this is not established yet (Contini et al., 2020). Therefore, researchers and scientists are still working for tracing out of its primary reservoir host (Tiwari et al., 2020).

In consideration of MERS, the infection spreads not only via respiratory secretion, and feces, but also milk; however, contaminated food is suggested as the transmission pathway (Contini et al., 2020). In addition, a few research presented the proof for nasal MERS viral shedding through sampling in significant number of camels at slaughter house (Farag et al., 2015; Contini et al., 2020). Although, there is no evidence as COVID-19 is a foodborne disease, however, the likelihood of SARS-CoV-2 being a food-borne CoV disease that is transmitted through the respiratory route cannot be ruled out (Jalava, 2020). However, there have a number of indirect impacts on food safety. Since the emergence of this disease, a several studies presented that COVID-19 virus remain viable on the surface for several hours. During purchase of food, if a diseased or asymptomatic patient 
touch the food or packets with contaminated hands, and shortly afterward, there have a great chance of exposure of infection to healthy peoples though handling of that food by hand, and finally virus may enter into body via mouth, nose, or eye (FDA, 2020; Desai and Aronoff, 2020). To avoid exposure of virus, wearing protective materials like masks and gloves, avoiding touching surface as much as possible, hand disinfection with alcohol based sanitizer or washing hand thoroughly with soap/detergents at least 20 seconds before and after leaving shop (Desai and Aronoff, 2020; Chen, 2020). The food may also be contaminated with COVID-19 virus during purchasing fresh and frozen food and transmission may happen before frozen. For example, several studies confirmed that MERS-CoV and SARS-CoV-1 can remain contagious up to 2 years in freezing condition. Therefore, food hygiene and good food safety measures are paramount to control viral transmission (Galanakis, 2020; Shariatifar and Molaee-aghaee, 2020).

\section{Food security during global lockdown}

As majority of the world's people are passing their lives in confinement due to lockdown of ongoing pandemic crisis since last week of March 2020 that has had impact on global food security (Galanakis, 2020; Business Insider, $2020^{\mathrm{b}}$ ). The wide scale lockdown has complicated the whole food supply chain from farm to table including food processing, supply and discharge, and consumption where people are engaged in different segments of supply chain, for example, agricultural inputs suppliers, farmers, food processers, wholesaler and vendors, transportation, and different organizations remain under hurdle (FAO, 2020 ${ }^{\mathrm{b}}$; Galanaki, 2020). Food stock would be limited if ongoing pandemic lockdown prolongs $\left(\mathrm{FAO}, 2020^{\mathrm{b}}\right.$ ). In addition, several recent studies reported that food supplies have been disrupted in a large-scale, as well as, people will get hungry rapidly even in twofold if each local government and associated institutions do not take remedial measures (The Guardian, 2020 a).

The measures taken by the government to prevent the transmission of the virus have led to transport standstill, making it difficult for farmers to access production inputs, preventing products from access to markets, and stopping consumers being able to purchase usually. Consequently, with limited supply, that caused price hike and demand to go down (FAO, 2020 $)$. The impact of COVID-19 on livestock value chain that disrupted food security and incurred colossal losses in Bangladesh (Table 1).

Table 1. Impact on supply chain of animal origin food that disrupted the food security and financial losses due to COVID-19 in Bangladesh.

\begin{tabular}{|c|c|c|c|}
\hline $\begin{array}{l}\text { Sector/ } \\
\text { Category }\end{array}$ & subcategory & $\begin{array}{l}\text { Loss in } \\
\text { million BDT }\end{array}$ & $\begin{array}{l}\text { Impact on supply chain that disrupts the food security Reference } \\
\text { and financial losses }\end{array}$ \\
\hline Poultry & $\begin{array}{l}\text { Poultry } \\
\text { - Meat } \\
\text { - Egg } \\
\text { - Poultry } \\
\text { feed along } \\
\text { with other } \\
\text { inputs }\end{array}$ & $\begin{array}{l}11,500 \text { million } \\
\text { in total } \\
1,000 \\
\text { million/day }\end{array}$ & $\begin{array}{l}\text { Poultry industry has experienced colossal loss due to The Business } \\
\text { country wide lockdown resulting sale of poultry chicken Standard, } 2020 \\
\text { dropped down between March } 20 \text {, to April 4, 2020. The and FAO, 2020 } \\
\text { farmers did not sale out the product what they are producing. } \\
\text { Bangladesh Poultry Industries Coordination Committee } \\
\text { (BPICC) claimed that situation of countrywide shutdown } \\
\text { has caused havoc in the poultry industry and selling price } \\
\text { below cost of production (broiler: Tk. 55-70/kg against } \\
\text { production cost Tk. } 118-128 / \mathrm{kg} \text {; egg } 4-4.8 / \text { piece against the } \\
\text { production cost Tk. 6-6.5/piece). Poultry and fish feed } \\
\text { production reduced } 70-75 \% \text {. Sale of poultry processed } \\
\text { product reduced } 95 \% \text {. Many poultry farms have been closed } \\
\text { particularly smaller-scale farms in rural areas. }\end{array}$ \\
\hline Dairy & Milk & $\begin{array}{l}570 \\
\text { million/day }\end{array}$ & $\begin{array}{l}\text { Bangladesh Dairy Farmers' Association (BDFA) mentioned The financial } \\
\text { that dairy farmers are in deep crisis because they are forced Express, } 2020^{\mathrm{b}} \\
\text { to sell milk at Tk } 10 \text { to } 12 \text { / litre in some production farms in } \\
\text { some areas while in other areas of the country they cannot } \\
\text { sell at all. Around } 12 \text { to } 15 \text { million litres of milk have } \\
\text { remained unsold for the last seven days in the wake } \\
\text { movement restrictions aimed at containing further spread of } \\
\text { the virus strains. The milk processing companies were found } \\
\text { to be uninterested to purchase milk at collection points. } \\
\text { There exists some } 0.3 \text { million dairy farms in the country and } \\
\text { some } 10.2 \text { million people depend on dairy farming both } \\
\text { forward and backward linkage were suffered. }\end{array}$ \\
\hline
\end{tabular}


4. Other natural events are likely to have impact on food security

At the side of the global lockdown due to pandemic situation of COVID-19, a few counties of Africa and South Asia have been experiencing of another global food security threat 'locust invasion plague' from middle of 2019 (BBC, 2020), therefore, millions of people will remain at starvation because of the locust invasion if proper measurements are not taken (FAO, 2020 $\left.{ }^{\mathrm{d}} ; \mathrm{CNN}, 2020\right)$. The desert locust is considered to be most dangerous of all migratory pest species due to its capacity to reproduce rapidly and destroy crops within shortest period of time. If not controlled, the locust numbers will multiply by up to 400 times by next few months and their rising numbers could turn a dire situation by the end of the year (FAO, 2020 ${ }^{\mathrm{d}}$; CNN, 2020; The Guardian, 2020 ) in combination with ongoing global COVID-19 pandemic situation.

In most recent time, Bangladesh and India has experienced another natural disaster, a powerful and deadly tropical cyclone "Amphan" that caused widespread damage by tsunamic upsurge of sea level, flood and cover the low land of Bangladesh which massively complicate the food production (flooding crop) and supply throughout the country. Approximately, $88 \%$ of farmers have been suffering from economic losses because of the effects of natural disaster beside of national lock down of COVID-19. In this situation, a lot of wet foods were wasted, farmers and associated food production farms were not able to supply or transport the product properly due to wreckage of road transportation system (The Daily Star, 2020 ${ }^{\mathrm{a}}$ ).

\section{Initiatives to avert the crisis}

To overcome this complex situation, government's authority in combination with private organization should give the first priority to keep the supply chain vibrant and ensure protection for production workers and its alienated actors of food supply chains (Galanakis, 2020). In this regards, the FAO has suggested for the availability of staple food on the basis of priority and the crops need to be transported to where they are needed most by minimizing restriction trade. However, FAO also has delivered some specific recommendations like expanding emergency food assistance programs along with social protection to keep people stay at home during lockdown, and providing instant support to the agricultural production of smallholders with the help of ecommerce by which farmers and farms can get instant payment of product and can continue the production during the state of emergency $\left(\mathrm{FAO}, 2020^{\mathrm{b}}\right.$; WHO/FAO, 2020 $)$. In addition, it proposes focusing on key logistics bottlenecks, for examples hampered food transportation across different territories and perishable food items like processed meat, fisheries, vegetables, and fruits. However, other factors are responsible to jump the food prices rapidly like imposing tax and trade policies and implementing fiscal measures (FAO, 2020 ${ }^{\mathrm{b}}$ ).

Apart from FAO suggestions, Bangladesh Armey has took some steps like 'one-minute bazaar' to keep food supply chain functional which is highly commendable. Since the low-income people have badly affected by the ongoing COVID-19 shutdown, can receive daily essential items for free of cost from this market. Bangladesh Army collects the vegetables from root-level farmers by paying good price with an aim to continue food supply chain lively during the shutdown (The Daily Star, $2020^{\mathrm{b}}$ ). Moreover, several initiatives through different projects taken by the government could help to avert the crisis like collection staple food commodities from the farmers with a correct price, distribution of 0.5 million tons of rice and 0.1 million tons of flour relief for poor venerable people for free of cost, supplying staple commodities with greater open market sale of rice at low price $(\mathrm{Tk} 10 / \mathrm{kg}$ ) for all, and Tk 7.60 billion financial assistance for millions of people those who lost their livelihood (The Financial Express, 2020').

Considering the vulnerability of the livestock value chains (poultry and dairy) the government actions are to be needed immediately to sustain the sector during the COVID-19 pandemic situation and to restore livelihoods of livestock and poultry raisers. Public awareness creation campaign should be conducted to promote the nutritional significance of animal origin foods (meat, eggs and milk) that will boost overall health and immunity, and to promote the information that livestock and poultry have no link with transmission of COVID19. Government intervention is required to continue regular imports and uninterrupted transportation of all farm inputs to keep the farmers in their business, and facilities for modern processing and cold storage to be ensured to preserve their product during the state of emergency. Farmers' cooperative society could be formed through which they can ensure availability on their products for the consumers that will allow them to get higher profits $\left(\mathrm{FAO}, 2020^{\mathrm{d}}\right.$ ).

\section{Control measures to reduce the spreading of foodborne illness}

Although COVID-19 is considered as zoonotic disease, but it generally spreads from person to person by inhaling virus containing droplets $(\geq 5-10 \mu \mathrm{m})$ and aerosols $(\leq 5 \mu \mathrm{m})$ exhaled from infected personnel during breathing, talking, coughing, and sneezing (Prather et al., 2020). 
To minimize the further transmission of COVID-19, there is urgent need to take measures to protect public health and infection control activities for limiting the spread of this virus. To minimize secondary infections among close contacts and healthcare personnel and to prevent transmission growing events even further release from the hotspot, it is very pertinent to delimit human-to-human transmission (Lai et al., 2020). On the basis of the earlier experience of controlling of MERS and SARS infections, a several recommendations for infection control interventions have been introduced by WHO to curtail the general risk of acquire of acute respiratory infections. To maintain a social distance (minimum $6 \mathrm{ft}$ ), covering face with qualitative mask, using hand gloves and goggles if going out for emergency purposes, frequently washing and sanitizing hands, to avoid touching face specially nose and eyes if hands are not properly sanitized, are some crucial preventive measures (WHO, $2020^{\mathrm{b}}$ ) which must be followed to reduce the risk of getting an infection by COVID-19. In addition, avoiding close contact with people suffering from acute respiratory infections, frequent cleaning hands especially after direct contact with ill people or their environment, and avoiding unprotected contact with farm or wild animals $\left(\mathrm{WHO}, 2020^{\mathrm{b}}\right)$. Although, WHO recommended to maintain minimum $6 \mathrm{ft}$ distance during talking with others, nevertheless, several researchers suggested that this is not enough as human exhaled respiratory droplets ranging 0.1-1000 $\mu \mathrm{m}$ (Prather et al., 2020), and these droplets can remain viable infectious airborne particles under several indoor condition, accumulate over time, and go behind air flows over distances more than $6 \mathrm{ft}$. Moreover, COVID-19 virus can spread more rapidly at outdoor because of the several factors including attaching of droplets with dust and pollutant which can alter the aerodynamic characteristics and increase transmission rate, and theses particle can spread at a long distance by breezes and winds (Conticini et al., 2020; Prather et al., 2020).

However, people who are suffering from acute respiratory infection should practice coughing and sneezing etiquette, cover coughs and sneezes using disposable tissues or clothing, and washing hands. In addition, within healthcare facilities this is mandatory to maintain improved standard infection prevention and control practices in hospitals, especially in emergency departments (Galanakis, 2020). Likewise, the US Centers for Disease Control and Prevention (CDC) has set up interim clinical guidelines for the SARS-CoV-2 outbreak to implement stringent measures to minimize the spread of COVID-19 in the USA. These guidelines entailed to identification of infected cases, their contacts in the country, proper risk assessment and care of travelers arriving from hotspot to the USA (Galanakis, 2020). These strategies are effective for identified infected persons, but remain challenge for the asymptomatic unidentified patients. Because of a significant proportion of the spread of COVID-19 cases appear to be occurring through airborne transmission of aerosols exhaled by asymptomatic persons during breathing and speaking which is very alarming matter specially for the confined environment, e.g. food, garments and pharmaceutical industry and other places, where a huge people work under a roof. To overcome of this problem considering industrial optimum productivity, universal masking and regular, widespread testing must be practiced urgently with an aim to identify and isolate infected asymptomatic patients (Prather et al., 2020). Food industry have the responsibility to ensure the production of safe food by implementing HACCP to certify safety standards are being followed. However, FAO suggested some measures for food processing industry to keep running smooth production by wearing personnel protective equipment during work to keep product safe from contamination. To provide proper training to all food workers about principle of food and personal hygiene, and how to spread respiratory infectious diseases is required. In addition, participatory awareness training on personal good health and hygiene practice on coughing, sneezing and sharing knowledge to all staff using pictorial display about the root cause of transmission, prevention and control of COVID-19, reducing staff by implementing multi-shift production plan to maintain maximum personto-person physical distance are necessitated (FAO, 2020 $;$ WHO/FAO, 2020 ${ }^{\mathrm{b}}$ ). Similarly, good health and hygienic practices should be implemented in all offices as obligatory by using masks for all, thermal checking and sanitizing hands during entrance and exit, and reporting personal health status from every staff based on self-responsibility.

\section{Risk cannot be averted; this is to be managed}

Since food safety is a complex health issue during COVID-19 pandemic situation. Therefore, the food safety hazards cannot be fully eradicated; however, these must be controlled along the whole strata of food supply chain from farm to table. Plummeting food safety hazards requires a solid collaboration among sectors, stakeholders and government agencies. The leadership on food safety issues and policymakers' commitment, coordination and partnerships across sectors, stakeholders and countries, allocation of sufficient resources and accountability by all concerned to be required for making a food safe. 


\section{Awareness of food safety}

Since food safety is a new approach in LMICs, it is relevant to aware the mass propels on safety concern during choosing a food. Unsafe food contaminated with harmful bacteria, viruses, parasites or even chemicals causes more than 200 diseases (Food Safety News, 2020 ${ }^{\mathrm{b}}$ ).

A timely reminder of the hazards posed by pathogens and the significance of good hygiene practices is well understood due to the current pandemic situation of COVID-19. The food is not the source or a vehicle of transmission of virus, however, the state of emergency has displayed as vividly as the impact of these diseases can reflect on public health and socio-economic safety. So, COVID-19 crisis has emphasized the vital role of preparedness, surveillance along with interdisciplinary collaboration at different (national, regional and international) levels as well as to ensure food hygiene from production to consumption. A vibrant food system is required through the coordinated efforts among the actors involved from government and nongovernment/private agencies as public private partnership (PPP) approach where food security and food safety are the utmost priorities during pandemic situation (Figure 1).

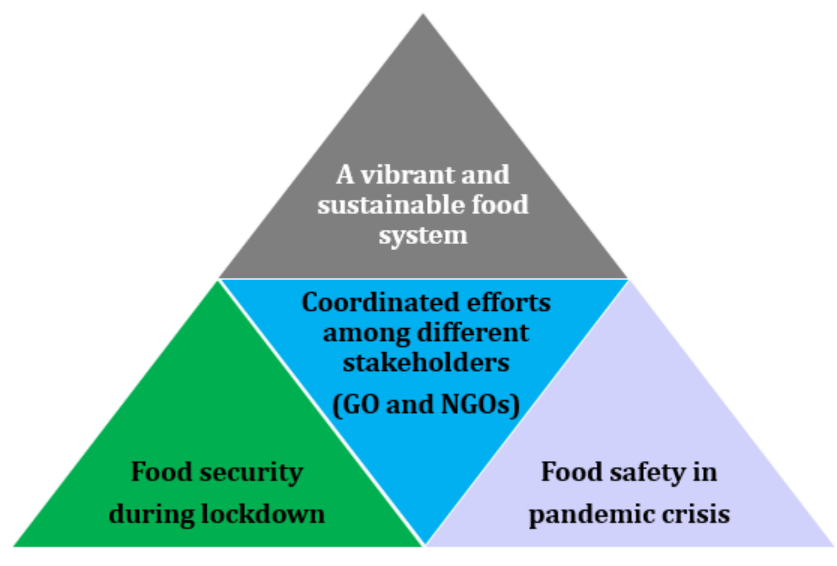

Figure 1. A vibrant and sustainable food system is obligatory to cope with the pandemic crisis that resulted through coordinated efforts among different stakeholders/agencies to address food safety and food security in low resource settings (adapted from Galanakis, 2020).

\section{Governments must play active role in food safety}

Governments have an important responsibility to play the pivotal role in food safety by assuring the full consideration and financing to make the safe food. The government authorities can assure that the consumers are getting safe food by certifying foods after proper laboratory confirmations. This involves the government must to have a robust food control system (Food Safety News, 2020 ${ }^{\mathrm{a}}$ ). For many countries in the world especially in LMICs this is still a challenge. They are working on the way to accommodating suitable infrastructure not only to harnessing regulations for food, moreover, to device them and to assist food producers to let them know what they are needed. They can also play a role to make together the different actors and sectors along the food supply chain and making sure that every person is conscious on importance of safety in food.

\section{Conclusions}

In conclusion, it is difficult to figure out the exact magnitude effects of COVID-19 for the humanity, worldeconomy, and food systems. However, the focus has yet to be given to managing the pandemic situation, major changes in policies and financing will be needed to preserve the advances have been obtained by a particular country over the past decades in food safety and food security perspectives. To ensure the food safety and security, and to decrease losses and waste of food, every nation including all stakeholders, government, nongovernment organizations, experts have to formulate a way forwards as an exerted effort. In addition, researcher and authority will have to face the challenges to ensure safe food for all and to find out the alternative food to tackle the food security crisis. Finally, consumer have to maintain good health and hygiene practice, should avoid to eat raw or undercooked food of animal origin, and should follow food safety key control measures. 
Conflict of interest

None to declare.

\section{References}

Business Insider, $2020^{a}$. Coronavirus: loss of smell and taste may be hidden symptom of COVID-19. Available: https://www.businessinsider.com/coronavirus-symptoms-loss-of-smell-taste-covid-19-anosmiahyposmia2020-3.

Business Insider, $2020^{\mathrm{b}}$. Countries that are on lockdown because of coronavirus. Available: https://www.businessinsider.com/countries-on-lockdown-coronavirus-italy-2020-3.

Cable News Network (CNN), 2020. The fight to contain a new locust invasion that could push millions into hunger. Available: https://edition.cnn.com/interactive/2020/05/africa/locusts/.

Center for Disease Control and Prevention (CDC), 2020. How coronavirus spreads. Available: https://www.cdc.gov/coronavirus/2019-ncov/prevent-getting-sick/how-covid-spreads.html.

Chen T, 2020. Reducing COVID-19 transmission through cleaning and disinfecting household surfaces. Vancouver, BC: National Collaborating Centre for Environmental Health.

Conticini E, B Frediani and D Caro, 2020. Can atmospheric pollution be considered a co-factor in extremely high level of SARS-CoV-2 lethality in Northern Italy? Environ. Pollut., 261: 114465.

Contini C, MD Nuzzo, N Barp, A Bonazza, RD Giorgio, M Tognon and S Rubino, 2020. The novel zoonotic COVID-19 pandemic: an expected global health concern. J. Infect. Dev. Ctries, 14: 254-264.

Desai AN and DM Aronoff, 2020. Food safety and COVID-19. JAMA, 323: 1982.

Farag EA, CB Reusken, BL Haagmans, KA Mohran, V Stalin Raj, SD Pas and MP Koopmans, 2015. High proportion of MERS-CoV shedding dromedaries at slaughterhouse with a potential epidemiological link to human cases, Qatar 2014. Infect. Ecol. Epidemiol., 5: 28305.

Food and Agriculture Organization (FAO), 2020 . Food Safety in the time of COVID-19. Food and Agriculture Organization, Rome, Italy. Available: https://doi.org/10.4060/ca8623en.

Food and Agriculture Organization (FAO), 2020 . COVID-19 and the risk to food supply chains: how to respond? Available: https://doi.org/10.4060/ca8388en.

Food and Agriculture Organization (FAO), 2020 . Value chain report no-1, June, 2020.

Food and Agriculture Organization (FAO), 2020 ${ }^{\mathrm{d}}$. Desert locust situation update (10 June 2020). Available: http://www.fao.org/ag/locusts/en/info/info/index.html.

Food and Drug Administration (FDA), 2020. Food Safety and availability during the coronavirus pandemic. Available at: https://www.fda.gov/consumers/consumer-updates/food-safety-and-availability-duringcoronavirus-pandemic. (accessed on 12 June 2020).

Food Safety News (FSW), 2020 . WHO: unsafe food continues to affect millions in Europe. Available: https://www.foodsafetynews.com/2020/06/who-unsafe-food-continues- to-affect-millions-in-europe/.

Food Safety News (FSW), 2020 ${ }^{\mathrm{b}}$. WHO: governments must play active role in food safety - expert. Available: https://www.foodsafetynews.com/2020/06/governments-must-play-active-role-in-food-safety-expert/.

Galanakis CM, 2020. The food systems in the era of the coronavirus (COVID-19) pandemic crisis. Foods, 9: 523.

Guo YR, C Qing-Dong, H Zhong-Si, T Yuan-Yang, C Shou-Deng, J Hong-Jun, T Kai-Sen, W De-Yunand and Y Yan, 2020. The origin, transmission and clinical therapies on coronavirus disease 2019 (COVID-19) outbreak - an update on the status. Military Medical Research, 7: 11.

Hobbs JE, 2020. Food supply chains during the COVID-19 pandemic. Can J Agr Econ. Pp. 1-6.

International Food Policy Research Institute (IFPRI), 2020. South Asia blogs and resources on COVID-19. Available: http://southasia.ifpri.info/2020/05/08/covid-19-blog-series-launch/

Jalava K, 2020. First respiratory transmitted food borne outbreak? Int. J. Hyg. Environ. Health, 226: 113490.

Lai CC, TP Shih, WC Ko, HJ Tang and PR Hsueh, 2020. Severe acute respiratory syndrome coronavirus 2 (SARS-CoV-2) and coronavirus disease-2019 (COVID-19): the epidemic and the challenges. Int. J. Antimicrob. Agents, 55: 105924.

Li W, Z Shi, M Yu, W Ren, C Smith, JH Epstein and J Zhang, 2005. Bats are natural reservoirs of SARS-like coronaviruses. Science, 310: 676-679.

Lu H, CW Stratton and YW Tang, 2020. Outbreak of pneumonia of unknown etiology in Wuhan China: the mystery and the miracle. J. Med. Virol., 92: 401-402.

Mahmoud B, 2020. The COVID-19 pandemic \& food safety: an eyewitness to the global war against the invisible enemy. Food Safety Magazine. Available: https://www.foodsafetymagazine.com/enewsletter/thecovid-19-pandemic-food-safety-an-eyewitness-to-the-global-war-against-the-invisible-enemy/. 
Prather KA, CC Wang and RT Schooley, 2020. Reducing transmission of SARS-CoV-2. Science, 2020: eabc6197.

Shahidi F, 2020. Does COVID-19 affect food safety and security? Journal of Food Bioactives, 9: 1-3.

Shariatifar N and E Molaee-aghaee, 2020. A novel coronavirus 2019 (COVID-19): important tips on food safety. J. Food Safe \& Hyg., 5: 58-59.

The British Broadcasting Corporation (BBC), 2020. How do you fight a locust invasion amid coronavirus? Available: https://www.bbc.com/news/world-africa-52394888.

The Business Standard, 2020. Poultry sector shares over a 1150 crore losses. Available: https://tbsnews.net/economy/industry/poultry-sector-stares-over-tk1150-crore-losses-63472.

The Daily Star, 2020 a . Farmers lost $\mathrm{Tk} 56,536$ cr to coronavirus (Brac surveys find). https://www.thedailystar.net/business/news/farmers-lost-tk-56536cr-coronavirus-1909317.

The Daily Star, 2020 b. Wonderful one-minute bazaar. The Daily Star (17 May, 2020). Available: https://www.thedailystar.net/backpage/news/wonderful-one-minute-bazaar-1903315.

The Financial Express, 2020 . Coronavirus (Covid-19) and food safety. Available: https://thefinancialexpress.com.bd/print/coronavirus-covid-19-and-food-safety-1587135507.

The Financial Express, $2020^{\mathrm{b}}$. Dairy farmers in trouble, seek govt. support. Available: https://thefinancialexpress.com.bd/public/index.php/trade/dairy-farmers-in-trouble-seek-govt-support1585369478.

The Financial Express, 2020 ${ }^{\mathrm{c}}$. COVID-19 pandemic and government response. Available: https://thefinancialexpress.com.bd/views/views/covid-19-pandemic-and-government-response-1588000220.

The Food and Drug Administration (FDA), 2020. Food safety and availability during the coronavirus pandemic. Available: https://www.fda.gov/consumers/consumer-updates/food-safety-and-availability-duringcoronavirus-pandemic.

The Guardian, 2020 a Coronavirus could double number of people going hungry | World news. Available: https://www.theguardian.com/world/2020/apr/09/coronavirus-could-double-number-of-peoplegoing-hungry.

The Guardian, $2020^{\mathrm{b}}$. Kenya's pastoralists face hunger and conflict as locust plague continues. Global development. Available: https://www.theguardian.com/global-development/2020/may/15/kenyaspastoralists-face-hunger-and-conflict-as-locust-plague-continues.

Tiwari R, K Dhama, K Sharun, MI Yatoo, YS Malik, R Singh, I Michalak, R Sah, DK Bonilla-Aldana and AJ Rodriguez-Morales, 2020. COVID-19: animals, veterinary and zoonotic links. Veterinary Quarterly, 40: 169182.

World Health Organization (WHO), 2020a . WHO Bangladesh COVID 19 Situation Report \#18. Available: https://www.who.int/docs/default-source/searo/bangladesh/covid-19-who-bangladesh-situation-reports/whocovid-19-update-18-20200629.pdf?sfvrsn=6ef8ba08_2.

World Health Organization (WHO), 2020 ${ }^{\mathrm{b}}$. Novel Coronavirus (2019-nCoV) Situation Report-18. Available: https://www.who.int/docs/default-source/coronaviruse/situation-reports/20200207-sitrep-18ncov.pdf?sfvrsn=fa644293_2.

World Health Organization (WHO)/Food and Agriculture Organization (FAO), 2020a. COVID-19 and food safety: guidance for food businesses: interim guidance, 07 April 2020. Available: https://apps.who.int/iris/handle/10665/331705.

World Health Organization (WHO)/Food and Agriculture Organization (FAO), 2020 . COVID-19 and food safety: guidance for competent authorities responsible for national food safety control systems: interim guidance, 22 April 2020. Available: https://apps.who.int/iris/handle/10665/331842

Yang D and JL Leibowitz, 2015. The structure and functions of coronavirus genomic 3' and 5' ends. Virus Res., 206: 120-133.

Yoo JH, 2020. The fight against the 2019-nCoV outbreak: an arduous march has just begun. J. Korean Med. Sci., 35: e56.

Zhou P, XL Yang, XG Wang, B Hu, L Zhang, W Zhang and HD Chen, 2020. A pneumonia outbreak associated with a new coronavirus of probable bat origin. Nature, 579: 270-273.

Yoo JH, 2020. The fight against the 2019-nCoV outbreak: an arduous march has just begun. J. Korean Med. Sci., 35: e56.

Zhou P, XL Yang, XG Wang, B Hu, L Zhang, W Zhang and HD Chen, 2020. A pneumonia outbreak associated with a new coronavirus of probable bat origin. Nature, 579: 270-273. 